\title{
VLIXES VERSUTUS: TOWARD A LATIN TRANSLATION OF ULYSSES ${ }^{1}$
}

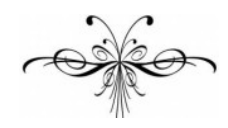

DAVID J. CALIFF

\begin{abstract}
In this essay, a few reasons why a translation of Ulysses into Latin might be useful are proposed. Moreover, speculations on the unique challenges Ulysses would pose for the Latin translator are laid out. Notwithstanding the many angles from which one might approach the task of translating Ulysses into Latin, one particular angle is taken here: the centuries-old tradition of translation as Latin composition. A few rules were set to guide this project. First, the language used must be Classical Latin - a Latin that Cicero or Vergil or Livy would recognize and not think particularly odd. Second, the translation must be literary, i.e. it must exhibit a stylized language, often of a particular author. Third, it should be creative, i.e. it should deal with both the ideas and linguistic nuances of the original text in a thoughtful and imaginative way.
\end{abstract}

Keywords: James Joyce; translation into Latin; Ulysses.
Resumo: Neste ensaio, algumas razões por quê uma tradução do Ulysses ao latim poderia ser útil são propostas. Além disso, algumas reflexões sobre os desafios únicos que o Ulysses colocaria para o tradutor ao latim são apresentadas. A despeito dos muitos ângulos possíveis a partir dos quais se poderia abordar a tarefa de tradução do Ulysses ao latim, toma-se aqui um ângulo particular: o da tradição centenária da tradução como composição em língua latina. Algumas regras foram definidas para orientar este projeto. Primeiro, a língua da empreitada deve ser o latim clássico - um latim que Cícero ou Virgílio ou Lívio reconhecessem e que não cressem particularmente estranho. Segundo, a tradução deve ser literária, i.e., deve exibir uma linguagem estilizada, mormente de um autor particular. Terceiro, ela deve ser criativa, i.e., deve lidar de maneira atenta e imaginativa tanto com as idéias quanto com as nuances linguísticas do texto original.

Palavras-chave: James Joyce; tradução ao Latim; Ulysses.

\footnotetext{
${ }^{1}$ I am pleased to offer my thanks to the delagates to the XXIII International James Joyce Symposium for their comments and insights as well as for the warm reception they gave to a nonJoycean classicist.
} 
$\mathrm{T}$

The obvious question that must occur to the reader of an article on translating James Joyce's Ulysses into Latin is, "Why?" After all, Latin is nobody's first language, so there can be no question of making the text available for the first time to the under-served community of native Latin speakers. Moreover, there is no commercial motive for such a translation. While we now have Latin editions of such classics as Winnie the Pooh, Green Eggs and Ham, Asterix, Harry Potter, and now The Hobbit, ${ }^{2}$ these translations have been purchased in large numbers by a generation of young Latin students who are eager to explore a beloved text in the difficult ancient language which they have been struggling to acquire. I think it is a safe bet that there are very few students out there who are just clamoring for a Latin translation of Ulysses.

In a similar way, teachers of such students also have found value in using translations of Pooh and Potter and others in the classroom. These translations show that Latin is, in its own way, very much "alive," and they have the potential pedagogical benefit of helping students achieve greater speed and fluency when reading extended passages of Latin. When a student encounters an unfamiliar word or construction, for instance, the knowledge of the original text can help her over that hurdle. It is very much the same principle as teaching Greek through the New Testament, as was done back in the day when students could be counted on to have a pretty good familiarity with the Bible.

Again, however, it is probably fair to say that there aren't many people (the present reader of this article excluded), let alone students, who have that kind of familiarity with Ulysses, and I'm not sure how much it would help even if they did.

So the question remains: why would anyone translate Ulysses into Latin? Well, the short answer is they wouldn't, but a longer answer is offered by the balance of this article. It will include an explanation of why one might actually want to translate at least an excerpt from Ulysses, what could be gained from doing so, and what unique challenges Ulysses would pose specifically for the Latin translator.

I believe that even if there is no good practical reason for such a translation, there is at least one good academic reason. There is a long tradition of translating literary passages in English (or Greek, or French, or German) into Latin. It is essentially an exercise in advanced Latin composition (prose or verse), and it is a tried-and-true step in the process of language acquisition.

While there are many angles from which one might approach the task of translating Ulysses into Latin, my focus will be on that particular centuriesold tradition of translation as Latin composition, which comes with its own set of rules. First, the language must be Classical Latin - a Latin that Cicero or Vergil or Livy would recognize and not think particularly odd. That means, among other things, no made-up words, only classical vocabulary. [I must confess that I always hated that rule since the ancient writers were constantly coin-

${ }^{2}$ Winnie Ille Pu, tr. Alexander Lenard, New York: Dutton, 1960. Viret Ova! Viret Perna!! tr. J.M. and T.O. Tunberg, Wauconda: Bolchazy-Carducci, 1993. Asterix Legionarius, tr. G.S. Martín, Stuttgart: Egmont Ehapa Verlag, 1999. Harrius Potter et philosophi lapis, tr. Peter Needham, London: Bloomsbury, 2003. Hobbitus Ille, tr. Mark Walker, London: HarperCollins UK, 2012. 
ing neologisms to expand upon Latin's relatively small stock of words, but it's not allowed, and it poses no small problem for a Joyce text.] Second, the translation must be literary, i.e. the stylized language, often of a particular author. Finally, it should be creative, i.e. it should deal with both the ideas and linguistic nuances of the original text in a thoughtful and imaginative way. That's a tall order.

To take it up to yet a higher level, there is within this tradition of academic Latin translation an equally long-standing custom of translating what might be called "unusual" texts, i.e. not classic poems or novels or passages from historians but nonsense verse, newspaper articles, excerpts from Punch and the like into Greek or Latin. Ulysses arguably fits that bill splendidly, and it poses, I think, a set of profitable challenges for the advanced student of Latin composition.

To begin, it forces the writer to think about the very idea of translation in a fairly sophisticated way. After all, the problem of translating Ulysses into Latin is a very old one - at least 2,300 and some odd years old. Of course, here I am using the word "translation" in a different, broader sense - the sense in which Joyce's Ulysses is already a translation (of a sort) of Greek epic. The problem that Joyce had to confront of how to "translate" an ancient Greek hero into a particular contemporary setting is a problem that Latin writers already had to confront over two millennia ago. When one does modern, academic Latin composition, it is necessary to reckon with that history, so reckon with it I will.

The case of Vergil is well-known to all, and I will come to him in a moment, but an equally instructive example is the lesser-known Livius Andronicus, the 3rd century BCE Latin poet who produced our first extant translation of Homer's Odyssey. Well, "extant" is a bit of a stretch: we have 46 disconnected lines, but we have them, including the self-reflexive first line, which shows Livius's awareness of this double meaning of "translation": "uirum mihi, Camena, insece uersutum" - "Camena [his muse], pursue for me the tale of the clever man." By rendering the Greek adjective polutropos as uersutus, Livius Andronicus produced a line that signals the complexity of the issue. The hero is not only "clever" and poly-tropic but also "well-versed" (with its poetic connotations) and even "translated" - all possible meanings of the Latin adjective: "Camena, tell me about the translated man."

Vergil's Aeneid similarly engages the Homeric texts as both translation and creative adaptation. The poet's opening phrase, arma virumque cano, shows the richness of that engagement.

Homer began the Iliad with the words: menin aeide thea Peleiadeo Achileos ("sing, goddess, about the rage of Achilles, the son of Pelias"). He began the Odyssey: Andra moi ennepe Mousa polutropon ("Tell me, Muse, about the crafty man"). Vergil's opening line of the Aeneid alludes to both, and in a somewhat Joycean way: arma uirumque cano Troiae qui primus ab oris ("I sing about arms and the man who first came from the coasts of Troy"). Vergil's arma (arms) recalls the Iliad, Homer's war epic about the rage of Achilles during the Trojan War, but it also echoes the sound of the first word of Homer's Odyssey. Arma and andra sound somewhat alike: both have two syllables, both are in the accusative case, both start and end with a, both have an internal $r$, and even the internal $\mathrm{n}$ and $\mathrm{m}$ are close in sound. Thus, in a single word Vergil alludes to 
both the Iliad and the Odyssey - the one by sense or meaning and the other by sound.

Anyone who doubts that Vergil is playing such a clever word game might be convinced by the great 17th-century English poet John Milton. The first lines of his epic Paradise Lost are: "Of man's first disobedience and the fruit / of that forbidden tree." "Man" literally translates the first word of Homer's Odyssey, but it sounds like the first word of the Iliad - menin. Surely this would have been familiar territory to the Jesuitically trained and linguistically astute Joyce.

In light of this background, a translator of Ulysses (again, in the academic tradition of Latin translation) must figure out how to render in Latin a text that is in a sort of English, ambiguously based on a once-oral "text" in a kind of Greek that has already been translated into an odd, old, Greekified Latin, and reclaimed by Rome's greatest writer.

Having said that, Joyce's highly allusive style, his self-conscious modernism, and his blending of history and the contemporary world all fit remarkably well with the literary culture of ancient Rome and could provide great creative opportunities. Moreover, while many of Joyce's particular avant-garde or experimental techniques are unprecedented in Latin literature, the experimental impulse is not, giving the Latin translator a "way in," so to speak.

A few minor practical problems can be solved with relative ease. Joyce's vocabulary is much larger than the vocabulary of all of Latin literature, to say nothing of the words that appear for the first time in print in Ulysses. Periphrasis is the only acceptable answer. There is Latin in Ulysses, even on the first page. Best answer: put it in Greek. There is extensive use of dialect; we have the model of Roman comedy for that. While these problems are no doubt more complex than such simple solutions suggest, there are accepted conventions to which the modern, academic translator is expected to conform.

Up until this point, this paper about translating Ulysses into Latin has been in the subjunctive mood: why would a person want to do it? How might he go about it? What would be the challenges? And I suppose I could end in the subjunctive as well, perhaps the optative: "would that somebody braver and more clever than I attempt such a translation!" Still, it will perhaps not go completely amiss to offer a few tentative examples.

As I made my way through Ulysses in search of a suitable passage, the first thing that caught my eye was the beginning of the "Nestor" chapter, when Stephen is teaching about King Pyrrhus of Epirus, a very Roman subject:

Had Pyrrhus not fallen by a beldam's hand in Argos or Julius Caesar not been knifed to death? They are not to be thought away. Time has branded them, and, fettered, they are lodged in the room of the infinite possibilities they have ousted. But can those have been possible, seeing that they never were? Or was that only possible which came to pass? Weave, weaver of the wind $\left(21^{3}\right)$.

It's a fine little passage, but in many ways it's a bit too easy: straightforward classical references, and vocabulary and sentence structure that work

\footnotetext{
${ }^{3}$ The page numbers refer to the Gabler edition. The fact that a whole range of textual issues exists for Ulysses is a subject of great interest to the classicist and a potential problem for the translator, but it is beyond the scope of this paper.
} 
equally well (or poorly) in Latin and English. More interesting are the few lines of verse (quoted by Joyce from Milton's Lycidas) that follow, and my attempt at putting them into Latin hexameters, the meter of pastoral:

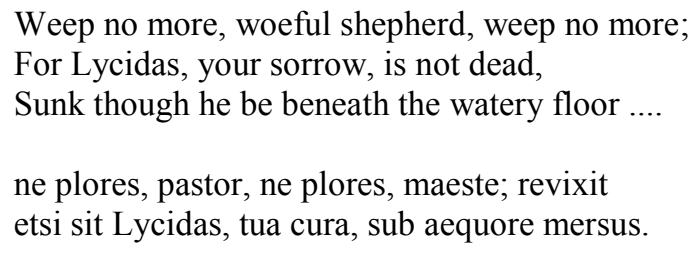

In the "Cyclops" chapter there is a parody of Homeric epithets, those usually- compound adjectives that are used to describe everything from characters to objects to places. Here's Joyce:

The figure seated on a large boulder at the foot of a round tower was that of a broadshouldered deepchested stronglimbed frankeyed redhaired freely freckled shaggybearded wide-mouthed largenosed longheaded deepvoiced barekneed brawnyhanded hairylegged ruddyfaced sinewyarmed hero (243).

I have endeavored to capture in Latin not only the "meaning" but also the rhythm and sound patterns, as well as the sense of parody:

Qui sedit in saxo magno sub turre rotunda erat heros humeris latis pectore alto fortibus artibus occulis candidis, rufus, libenter lentiginosus [freckled] barba horrida ore lato naso magno capite longo voce gravi genu nuda manibus lacertosis cruris hirsutis vultu rubra bracchiis nervosis.

An even more revealing passage is the beginning of "Oxen of the Sun". I must confess to having lacked the nerve to attempt the very opening lines, but the first big paragraph is a pretty good passage to set for translation along the lines I have been discussing:

\begin{abstract}
Universally that person's acumen is esteemed very little perceptive concerning whatsoever matters are being held as most profitable by mortals with sapience endowed to be studied who is ignorant of that which the most in doctrine erudite and certainly by reason of that in them high mind's ornament deserving of veneration constantly maintain when by general consent they affirm that other circumstances being equal by no exterior splendour is the prosperity of a nation more efficaciously asserted than by the measure of how far forward may have progressed the tribute of its solicitude for that proliferent continuance which of evils the original if it be absent when fortunately present constitutes the certain sign of omnipollent nature's incorrupted benefaction (314).
\end{abstract}

The syntax is obviously difficult and ambiguous. "Perceptive" comes from Latin, yet there is oddly no Latin word that captures the exact meaning. "Most in doctrine erudite" sounds Latinate, and it is Latinate in vocabulary but not in syntax, even though it seems so. And "by reason of that in them high mind's ornament" works as perfectly good Latin if you take "that" with "ornament," even though there is no necessity to do so. "Omnipollent" is a problem, because you can't make up words like that, but you can use multiple words to capture the slippage, at least partially, but there is no exact word for "pollen." I wrote, "omnipotens seminansque." Having semen involved in "nature's 
incorrupted benefaction" seems like something Joyce would like. The resulting Latin is arguably more "normal" than the English original (as perhaps it must be in this exercise), but I hope it at least gives a minimal sense of how Latin can and cannot handle Joyce.

Here is an attempt at the first part of the passage (up to "maintain"):

Huius acumen ingenii universe parvi aestimatur, attentum de quibuscumque a mortalibus sapientiae praeditis studendis utiliter habentur, quis nescit quod doctrina eruditissimi et certe hac de causa qualecumque in eis ornamentum mentis altae venerandae assidue affirment ...

That's as far as I dare go. It would be fun to try some of "Penelope," but since there is no word - certainly no single word - for "yes" in Classical Latin ${ }^{4}$, I really wouldn't know where to begin!

David J. Califf

ovid43@mac.com

PhD, Professor, The Academy of Notre Dame de Namur, USA

\footnotetext{
${ }^{4}$ Thanks to Sam Slote for the observation that Irish also has no single word for "yes" - a wonderful coincidence!
} 